
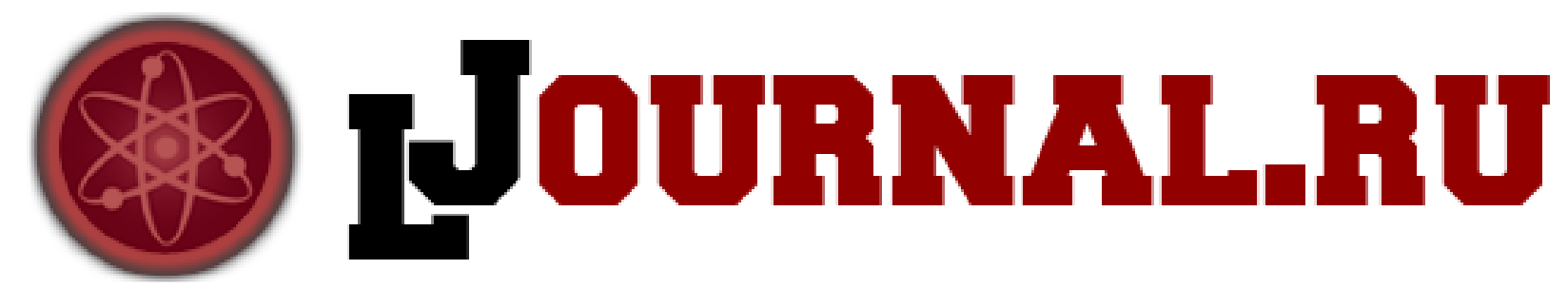

Старожилов В.Т.

Дальневосточный федеральный университет Россия, Владивосток

doi: 10.18411/1j2016-2-24

\title{
Ландшафтная география окраинно-континентальных округов восточно- сихотэ-алинской геосистемы
}

На современном этапе развития ландшафтной географии Тихоокеанской России вопросы ландшафтного районирования практически не решаются. Хотя, в связи с наметившимся на государственном уровне освоением территории, учету природных условий отводится значимое место. Работа включает результаты многолетних авторских научных и практических исследований в сфере геолого-географического изучения и ландшафтного картографирования крупных региональных Приморского, Сахалинского и др. звеньев окраинноконтинентального ландшафтного пояса Тихоокеанской России. Они тематически продолжают ландшафтное картографирование и описание России и региональных её звеньев, a среднемасштабное картографирование с использованием регионально-типологической классификации позволило отразить особенности геосистем, проявляющие в различных частях их ареалов, а описание выявило свойства и степень различия между ландшафтными геосистемами. Эта территория вошла в ландшафтные карты СССР масштабов 1: 2500000 [2] и 1: 4000000 [1], ландшафтную карту Сахалинской области в масштабе 1: 2000000 [3], в ландшафтную векторную карту Приморского края в масштабе 1: $1000000[6,7]$ и др. 
Включает обширную сопряженную природную информацию. Изучались соотношения и взаимосвязи достаточно значимых выборок данных не только по рельефу, растительности и почвам, но и коренным и рыхлым породам, климату. Также изучались мощность рыхлых накоплений, транзит обломочного материала, увлажнение, глубина вреза, густота расчленения, интенсивность физического и химического выветривания, мезо- и микроклиматические особенности [4].

Весь имеющийся материал проанализирован на основе сопряженного анализа и синтеза межкомпонентных и межландшафтных связей с учетом окраинно-континентальной дихотомии и данных по орографическому, климатическому и фиторастительному факторам географически единых территорий в рамках горной ландшафтной географии. В результате на примере Приморского края и Сахалинской области в масштабе 1:500 000 выделены и картографированы классы, подклассы, роды, виды ландшафтов и местности (индивидуальные ландшафты) [7] . Далее материал уже на базе выделенных таксонов на основе изучения межкомпанентных и межландшафтных связей снова сопряженно проанализирован и были снизу в верх выделены и закартографированы округа, провинции и области. В частности только по Приморскому краю выделено 54 округа [8]

В статье рассматриваются методология выделения и внутреннее содержание округов на примере округов только Северо-Сихотэ-Алинской провинции Восточного Сихотэ-Алиня, так как рассмотреть все округа в статье просто не возможно (рис 1).

Округа обособляются внутри провинций, включают ландшафты видов и местностей, определяемые высотностью, типами растительности и группировками почв, рельефом и вешественными комплексами фундамента. Всем ходом физико-географического развития любых территории предопределены не только формирование и эволюция географически единых областей, провинций, но и дифференциацию территорий по геолого- 
геоморфологическим особенностям в сочетании с почвенно-растительным разнообразием. Сопряженное сочетание отмеченных компонентов нами проведено ранее при изучении регионально-компонентной специфики и пространственном анализе геосистем Приморья [4]. В результате такого сопряженного анализа компонентов выделены и показаны на картах определенное количество местностей и видов ландшафтов. Поиск закономерностей в структуре и организации ландшафтов, с учетом дифференциации местностей и видов и с учетом почвенно-растительного разнообразиия, а также учетом глубинных корней окраинно-континентальной дихотомии дал возможность выявить и показать на картах определенное количество округов ландшафтов.

Кроме того, при обособлении округов учитывались не только особенности провинциальной и в целом природы выделяемого нами Тихоокеанского окраинно-континентального ландшафтного пояса [5], но и региональные природные особенности например Восточного Сихотэ-Алиня и его внутреннее содержание. В частности, Восточный Сихотэ-Алинь это ассиметричный Япономорский склон Сихотэ-Алинской горной территории, вытянут в северовосточном направлении вдоль побережья Японского моря, отделен от западного склона главным Сихотэ-Алинским водоразделом, создающим природноклиматические особенности. Поскольку только до линии главного водораздела распространяется циркуляция переувлажненных холодных масс, поступающих с Охотского и Японского морей в весенной - раннелетний период и относительно теплых масс - в оснне - зимний. В обособлении округов учитывалось генетическое и географическое структурно - тектоническое положение вещественных комплексов Восточного Сихотэ-Алиня, как частей сводовых поднятий единой геолого-географической структуры Восточного вулканического пояса Тихоокеанского окраинно-континентального ландшафтного пояса. В целом географическое единство любых округов определяется сочетанием орографического (рельеф, вещественные комплексы) 
климатического (климат) и фиторастительного факторов, с учетом информационного уровня и провинциального масштаба объекта исследования.

В предлагаемом читателю статье, в качестве примера, рассматриваются округа Северо-Сихотэ-Алинской провинции: Верхне-Единский, ВерхнеБикинский. По другим округам провинции для сравнения приводятся только природно-ландшафтные данные (табл.1)

Верхне-Единский округ расположен в верхних течениях рек Единка и Кабанья (рис. 1, на схеме - 1). Характеризуется природно-ландшафтными статистическими данными (табл. 1). Включает горную территорию дальневосточного горного класса ландшафтов с ландшафтами доминантного горно-темнохвойного и редкого горно-тундрового подклассов, доминантного расчлененносреднегорного полисубстратного род

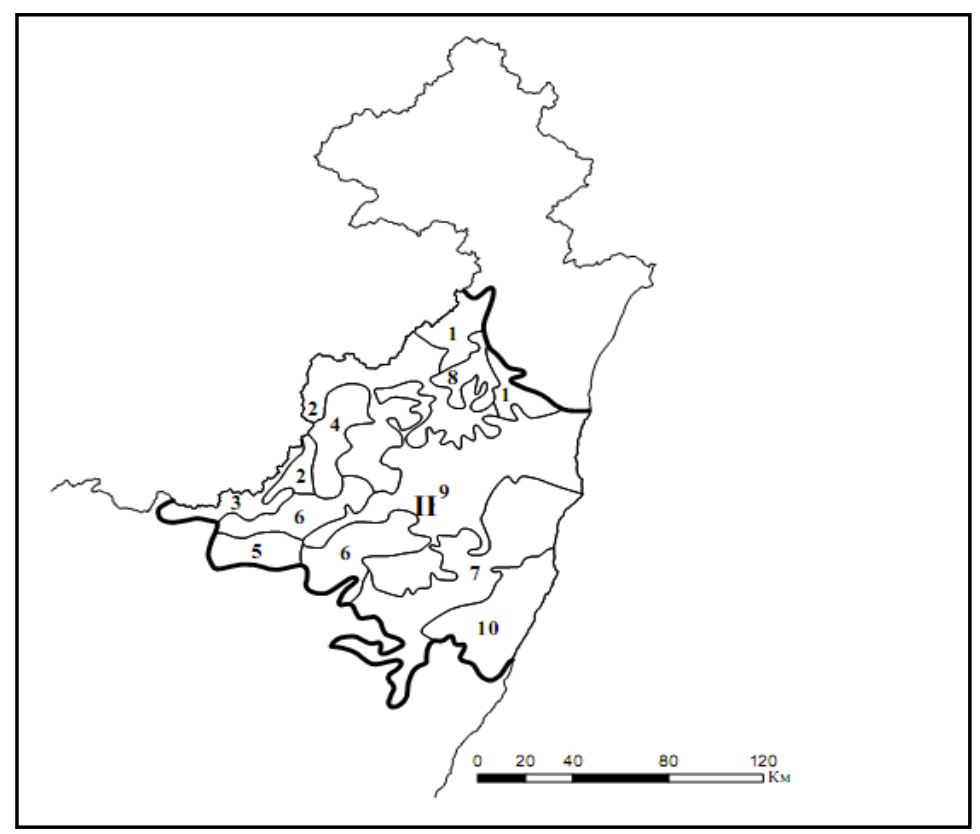

Рис. 1. Пространственное положение Верхне-Единского (1) и Верхне-Бикинского (2) ландшафтного округов (Северо-Сихотэ-Алинская ландшафтная провинция) 
Природно-ландшафтная дифференцииация округов

Северо-Сихотэ-Алинской провинции

\begin{tabular}{|c|c|c|c|c|c|c|c|c|}
\hline $\begin{array}{l}\text { 㝘 } \\
\text { 言 }\end{array}$ & 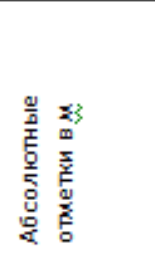 & 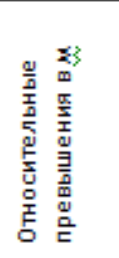 & 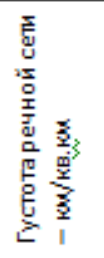 & 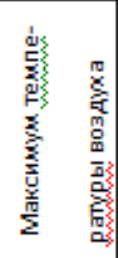 & 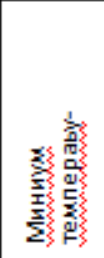 & 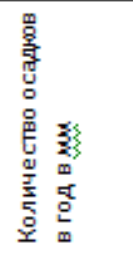 & 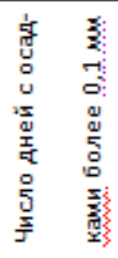 & 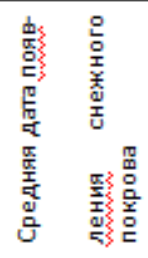 \\
\hline 1. ReqXнее-Еяинский & $350-1668$ & $400-600$ & $0,6-1,0$ & 36 & 48 & $700-800$ & $130-140$ & $10-20.10$ \\
\hline 2. Верххнее-Бикинский & $500-1933$ & $400-500$ & 0,6 & 37 & -50 & $700-900$ & $130-140$ & $10-20.10$ \\
\hline 3. Reяхне-Катенский. & $800-1758$ & $600-900$ & $0,6-0,8$ & 35 & -45 & $800-900$ & $140-150$ & $10-20.10$ \\
\hline 4. Ключевой & $1100-1747$ & $400-600$ & 0,6 & 35 & -40 & $800-1000$ & $140-150$ & $10-20.10$ \\
\hline 5. Родниковый & $150-400$ & до 250 & $0,6-0,7$ & 36 & -49 & $700-800$ & $140-150$ & $20.10-1.11$ \\
\hline 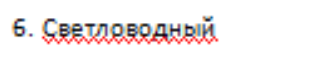 & $300-1200$ & $300-500$ & $0,6-0,8$ & 34 & -42 & $700-800$ & $150-160$ & $10-20.10$ \\
\hline 7. Қхзненцовскицй & $0-1364$ & $400-600$ & $0,6-1,0$ & 35 & -38 & $600-800$ & $110-150$ & $10-20.10$ \\
\hline 8. Единскогсе плато & $200-1200$ & $200-400$ & 0,6 & 35 & -45 & $700-800$ & $120-140$ & $10-20.10$ \\
\hline 9. Девинскоге плато & $0-1350$ & до 600 & $0,6-1,0$ & 35 & -45 & $700-1000$ & $130-150$ & $10-20.10$ \\
\hline 10. Максиморескоге плато & $0-940$ & до 600 & $0,6-1,0$ & 34 & -40 & $700-1000$ & $110-140$ & $20.10-1.11$ \\
\hline
\end{tabular}

Для округа доминанты - верхне-единский и верхне-кабаний расчлененносреднегорный пихтово-елово-лиственичный и зеленомошный виды горно- темнохвойного пояса и включают комплекс пихтово-еловых, лиственничных, елово-лиственичных и мелколиственных лесов (местами с широколиственными породами) на горно-таежных бурых и др. почвах Имеют быстрый водообмен.

Доминантные местности включают верхне-единский и верхне-кабаний расчлененносреднегорные пихтово-елово-лиственичные на горно-таежных бурых и др. почвах с алевролит-песчаниковым, верхнемеловым вулканитовым кислого и среднего состава фундаментом и глубиной залегания кровли коренного фундамента до 3,0 - 5, 0 м и др. местности.

Редкие местности - горно-тундровые гольцовые среднегорные лишайниково-кустарниковые на горно-тундровых почвах с алевролитпесчаниковым и вулканитового состава фундаментом и глубиной его залегания до 1,7 м. 
Верхне-Единский округ обособляется по отмеченному выше внутреннему его содержанию, по доминантным среднегорному рельефу, алевролитпесчаниковому и вулканитовому фундаменту, горно-таежным бурым почвам и темнохвойным лесам. В современное время округ это единая часть среднегорного сводового поднятия (в прошлом активной окраины континента), фундамент единая структурная и азональная вещественно-минеральная основа округа, на которой сформировался доминантный темнохвойный комплекс лесов. Генетическое и географическое единство отмеченных орографического (рельеф, вешественные комплексы), климатического (муссонный климат), фиторастительного (растительные комплексы) факторов обуславливают географическое обособление Верхне-Единского округа.

Верхне-Бикинский округ расположен в верховье р. Бикин (рис. 1, на схеме 2). Характеризуется природно-ландшафтными статистическими данными (табл. 1). Включает горную территорию дальневосточного горного класса ландшафтов с ландшафтами доминантного горно - смешанношироколиственного, редких горно-темнохвойного и горно-тундрового подклассов, доминантного расчлененносреднегорного полисубстратного рода.

Для округа доминанты - верхне-бикинский расчлененносреднегорный лиственично-хвойно-смешанный и мелколиственный виды горно- смешанношироколиственного пояса и включают комплекс мелколиственных лесов горных заболоченных широких долин рек и межгорных котловин в комплексе с участками хвойных и смешанных лесов на горно-таежных бурых и др. почвах. Встречается среднегорнорасчлененный пихтово-елово-лиственичномелколиственный вид с комплексом пихтово-еловых, лиственничных, еловолиственичных и мелколиственных лесов (местами с широколиственными породами) на месте старых возобновившихся гарей на горно-таежных бурых и др. почвах.

Редкий - среднегорнорасчлененный горно-тундровый лишайниково- 
кустарниковый вид.

Доминантные местности включают верхне-бикинские расчлененносреднегорные лиственично-хвойно-смешанные и мелколиственный на горно-таежных бурых и др. почвах с алевролит-песчаниковым фундаментом и глубиной залегания кровли коренного фундамента до 3,0 - 5, 0 м и др. местности.

Редкие местности- верхне-бикинские горно-тундровые гольцовые среднегорнорасчлененные лишайниково-кустарниковые на горно-тундровых почвах с алевролит-песчаниковым и др. состава фундаментом и глубиной его залегания до 1,0 м.

Верхне - Бикинский округ обособляется по отмеченному выше внутреннему его содержанию, по доминантным среднегорному рельефу, алевролит-песчаниковому фундаменту, горно-таежным бурым почвам и смешанно-широколиственным лесам. В современное время округ это единая часть среднегорного сводового поднятия (в прошлом окраинного моря континента), фундамент единая структурная и азональная вещественноминеральная основа округа, на которой сформировался доминантный смешанношироколиственный комплекс лесов. Генетическое и географическое единство отмеченных орографического (рельеф, вешественные комплексы), климатического (муссонный климат), фиторастительного (растительные комплексы) факторов обуславливают географическое обособление Верхне Бикинского округа.

Итак, завершая рассмотрение методологии выделения и характеристику внутреннего содержания примеров индивидуальных округов важно отметить, что географическое обособление округов, как одного из таксонов Восточного Сихотэ-Алиня окраинно-континентального ландшафтного пояса России обуславливают индивидуальное генетическое и географическое единство отмеченных выше орографического (рельеф, вешественные комплексы), климатического (муссонный климат), фиторастительного (растительные 
комплексы) факторов. Кроме того нужно подчеркнуть важность полученных результатов ландшафтного районирования. Это связано, прежде всего, с необходимостью использования полученных материалов как ландшафтной основы оптимизации природопользования. Рекомендуется применять материалы по районированию территорий как ландшафтные основы проведения природоохранных, экологических, мониторинговых и др. мероприятий. Кроме того применять их при разработке метадологии выделения ландшафтных таксонов и изучении внутреннего содержания ландшафтов в рамках ландшафтной географии Тихоокеанской России. 


\section{Литература:}

1. Исаченко А.Г. (науч. редактор). Ландшафтная карта СССР. Масштаб 1: $4000000,1985$.

2. Ландшафтная карта СССР масштаба 1: 2500 000. Министерство геологии СССР. Гидроспецгеология. Отв.Ред. И.С. Гудилин. - М, 1980.

3. Нефедов В.В. Ландшафтная карта Сахалинской области масштаба 1: 2000 000. Атлас Сахалинской области.- М.,1967.

4. Ландшафтная география Приморья, часть 1. (регионально-компонентная специфика и пространственный анализ геосистем): монография / B.T. Старожилов. - Владивосток: Изд-во Дальневост. федерал. ун-та, 2013.- 276 c.

5. Старожилов В.Т. 2013. Тихоокеанский окраинно-континентальный ландшафтный пояс как географическая елиница Тихоокеанской России и вопросы практики // Проблемы региональной экологии.- М., 2013 - №5. - С. $1-7$.

6. Старожилов В.Т. Карта ландшафтов Приморского края масштаба 1: 1000 000. - Владивосток: Изд-во Дальневост. ун-та. 2009

7. Старожилов В.Т. 2009. Ландшафты Приморского края масштаба $1:$ 500000 (Объяснительная записка к карте масштаба 1: 500 000). Владивосток: Изд-во Дальневост. ун-та, - 368 с.

8. Старожилов В.Т. Ландшафтная география Приморья. Книга 2 (районирование): монография / В.Т. Старожилов. - Владивосток: Издательский дом Дальневост. федерал.ун-та, 2013 а. - 272 с. 